\title{
Screening and Association of Polymorphism in Alpha-Lactalbumin Gene in Holstein Friesian Crossbred Cattle
}

\author{
Rohish Kaura $^{1}$, Simarjeet Kaur ${ }^{1 *}$, J.S. Arora ${ }^{2}$ and Neeraj Kashyap ${ }^{1}$ \\ ${ }^{1}$ Department of Animal Genetics and Breeding, Guru Angad Dev Veterinary and Animal Sciences University, Ludhiana, \\ Punjab, INDIA \\ ${ }^{2}$ Department of Animal Biotechnology, Guru Angad Dev Veterinary and Animal Sciences University, Ludhiana, Punjab, INDIA \\ *Corresponding author: S Kaur; E-mail: simarsharma08@gmail.com
}

Received: 05 Feb., 2021

Revised: 23 May, 2021

Accepted: 25 May, 2021

\begin{abstract}
This study was done to monitor milk protein variations in $\alpha$-lactalbumin gene (LALBA) and to determine possible associations with various performance traits in Holstein Friesian (HF) crossbred cattle. Present study was conducted on 546 records of $60 \mathrm{HF}$ crossbred cattle maintained at livestock farms, Guru Angad Dev Veterinary and Animal Sciences University, Ludhiana, Punjab. The records consists of data pertaining to weight at first calving (WFC), first lactation milk yield (FLMY), first lactation 305days milk yield (FL305-dMY), first lactation length (FLL), first peak yield (FPY), days to attain peak yield (DPY), age at first calving (AFC), first service period (FSP), first dry period (FDP) and first calving interval (FCI). PCR-RFLP technique was used to categorize the different alleles in the population. Genetic polymorphism was recognized by using $M n l I$ restriction enzymatic digestion followed by agarose gel electrophoresis. The test revealed occurrence of two genetic variants " $\mathrm{A}$ " and "B" for LALBA gene which was further confirmed by performing sequencing of amplified fragments. Sequence alignment revealed 2 SNP's in the whole $166 \mathrm{bp}$ fragment, one SNP is present in the 5'UTR region of exon and one in promoter region. Gene regulation study revealed "Antp" transcription factor not binding at 35 to $44 \mathrm{bp}$ due to point mutation at $37 \mathrm{bp}$ of $\mathrm{A}>\mathrm{G}$, suggesting modulation of transcription. Association study showed significant $(\mathrm{p} \leq 0.05)$ relation of LALBA gene "BB" genotype with high first lactation peak yield (FLPY). Further investigations are required to elucidate the biological and practical relevance of these SNP's and change in transcription factor.
\end{abstract}

\section{HIGHLIGHTS}

( Alpha - lactalbumin gene associations with various performance traits in Holstein Friesian (HF) crossbred cattle.

( Association of different genotypes with performance traits in Holstein Friesian (HF) crossbred cattle.

Keywords: Holstein Friesian crossbred cattle, $\alpha$-lactalbumin gene, SNP, PCR-RFLP

Number of studies in the past has looked upon the relationship between milk protein genetic variants and diverse milk production traits. Many studies had shown the prospect of using milk protein as a polymorphic genetic marker. Among milk protein genes, genetic variants of LALBA gene such as A and B, has been reported in crossbred cattle. In dairy cattle the loci responsible for milk production and protein and fat content have received considerable attention. Molecular markers are specific pieces of DNA that can be identified within the genome and are inherited according to Mendel's laws of inheritance.
At present, SNP's (Single Nucleotide Polymorphism) represent the most innovative molecular markers in genotyping studies. On the other hand, recent advances in high- throughput DNA sequencing and bioinformatics have facilitated and improved the identification of Single Nucleotide Polymorphism (Teneva and Petrović, 2010). LALBA gene encoding $\alpha$ - lactalbumin is localized

How to cite this article: Kaura, R., Kaur, S., Arora, J.S. and Kashyap, N. (2021). Screening and association of polymorphism in Alpha-lactalbumin gene in Holstein Friesian crossbred cattle. J. Anim. Res., 11(3): 351-355. Source of Support: None; Conflict of Interest: None क्ष 
on chromosome 5 (BTA5q12-13) and it consists of 4 exons with the length of $3061 \mathrm{bp}$. The polymorphism of this gene is observed in cattle breeds deriving directly from Bos indicus (Barlowska et al., 2012). The use of polymorphic genes as detectable molecular markers is a promising alternative to the current methods of trait selection once these genes are proven to be associated with traits of interest in animals (Zaglool et al., 2016). The constant monitoring of the milk protein variations in various breeds of cattle is an essential practice aiming to increase the frequency of genetic variants with favorable effects and to adapt their utilization for marker-assisted selection and breeding of cows (Hristov and Radoslavov, 2015). The vital role for building any selection or breeding programme is to first recognize the genetic properties of lactation and performance traits. As a large number of genetic and non-genetic factors affect the lactation traits, adjustment of effects of genetic and non-genetic factors is crucial for correct, precise and impartial estimates of genetic parameters.

As a means to boost the productivity, it is imperative to develop knowledge about the factors affecting milk production, reproduction and growth in dairy cattle. The economic returns from an animal are not only based on its milk production alone but also on its growth and reproductive performance. Molecular characterization at an early age can help to improve milk yield by reinstating conventional selection methods. The outcome of this research will be useful for selection programs for $\mathrm{HF}$ crossbred cattle.

\section{MATERIALS AND METHODS}

Present study was conducted on 546 records of $60 \mathrm{HF}$ crossbred cattle maintained at livestock farms, Guru Angad Dev Veterinary and Animal Sciences University, Ludhiana, Punjab. The records included data related to weight at first calving (WFC), milk production traits viz. first lactation milk yield (FLMY), first lactation 305-days milk yield (FL305-dMY), first lactation length (FLL), first peak yield (FPY), days to attain peak yield (DPY) and reproductive performance traits viz. age at first calving (AFC), first service period (FSP), first dry period (FDP) and first calving interval (FCI). Non-genetic factors viz. period of calving, season of calving and age at first calving (mean $\pm 0.5 \mathrm{SD}$ ) were classified into subclasses to assess the effects of non-genetic factors on different milk production and reproductive performance traits by using least squares analysis for non-orthogonal data (Harvey, 1990). To study the relationship between genetic variants of $\alpha$-lactalbumin gene and milk production and reproductive performance traits the data already corrected for effects of non-genetic factors were used. The corrected value for milk production and reproductive performance traits was arranged for the animals against the genotypes for the found SNP and least square analysis of variance was carried out using the General Linear Model (GLM) procedure of SAS version 9.3. The chi-square test was carried out to determine whether the observed genotype frequencies deviate significantly from HW equilibrium.

\section{DNA extraction}

Blood samples for DNA extraction were taken from 60 HF crossbred cattle maintained at livestock farms, Guru Angad Dev Veterinary and Animal Sciences University, Ludhiana, Punjab. Genomic isolation of DNA was done from whole blood using phenol- chloroform-isoamyl alcohol method (Sambrook and Russell, 2001) with slight modifications.

\section{PCR-RFLP}

LALBA gene genotyping were performed by a simple polymerase chain reaction with specific primers reported by (Vătăsescu-balcan, 2008) followed by enzymatic restriction digestion (Table 1).

Table 1: Forward and reverse primer sequences used for amplification of LALBA gene

\begin{tabular}{lll}
\hline Primer & Primer Sequence & $\begin{array}{l}\text { Size of } \\
\text { Amplicon }\end{array}$ \\
\hline$\alpha$-LA & $5^{\prime}$-CTCTTCCTGGATGTAAGG & \\
Forward & CTT-3' & $166 \mathrm{bp}$ \\
\hline$\alpha$-LA & $5^{\prime}$-AGCCTGGGTGGCATGGAA & \\
Reverse & TA-3' & \\
\hline
\end{tabular}

Genomic DNA was amplified for 45 cycles in a $25 \mu \mathrm{l}$ volume reaction with following reaction mixture (Table 2). PCR program for amplification for $\alpha$-lactalbumin genomic DNA includes initial denaturation of $95^{\circ} \mathrm{C}$ for $5 \mathrm{~min}$, cyclic denaturation of $95^{\circ} \mathrm{C}$ for $30 \mathrm{sec}$, cyclic annealing of $58^{\circ} \mathrm{C}$ for $30 \mathrm{sec}$, cyclic extension of $72^{\circ} \mathrm{C}$ for 
$1 \mathrm{~min}$ with final extension of $72^{\circ} \mathrm{C}$ for $5 \mathrm{~min}$ and storage for 10 min at $4^{\circ} \mathrm{C}$.

Table 2: Optimized PCR reaction mixture

\begin{tabular}{llll}
\hline $\begin{array}{l}\text { Sl. } \\
\text { No. }\end{array}$ & Reaction Components & Volume & $\begin{array}{l}\text { Final } \\
\text { Concentration }\end{array}$ \\
\hline 1 & $10 \mathrm{X}$ PCR buffer & $2.5 \mu \mathrm{l}$ & $1 \mathrm{X}$ \\
2 & $10 \mathrm{Mm} \mathrm{dNTPs}$ & $0.5 \mu \mathrm{l}$ & $200 \mu \mathrm{M}$ \\
3 & $25 / 50 \mathrm{MgCl}_{2}$ & $1.25 \mu \mathrm{l}$ & $2.5 \mathrm{mM}$ \\
4 & Forward primer $(\mathrm{mM})$ & $1 \mu \mathrm{l}$ & $10 \mathrm{pmol} / \mu \mathrm{l}$ \\
5 & Reverse Primer $(\mathrm{mM})$ & $1 \mu \mathrm{l}$ & $10 \mathrm{pmol} / \mu \mathrm{l}$ \\
6 & $5 \mathrm{U} / \mu 1$ Taq DNA polymerase & $0.5 \mu \mathrm{l}$ & $5 \mathrm{U} / \mu \mathrm{l}$ \\
7 & Nuclease Free Water & $16.25 \mu \mathrm{l}$ & - \\
8 & Genomic DNA (Template) & $2 \mu \mathrm{l}$ & $100 \mathrm{ng} / \mu \mathrm{l}$ \\
& Total & $25 \mu \mathrm{l}$ & \\
\hline
\end{tabular}

\section{Digestion protocol}

PCR products were digested with restriction endonuclease MnlI with recognition frame of GAGG(N) $\downarrow$ 然ites (Thermo Scientific). Optimization of restriction enzyme (RE) digestion and digestion conditions followed as per the manufacturers recommendations.

\section{Gel electrophoresis of RE digested PCR product}

$2 \mu 1$ of $6 \mathrm{X}$ loading dye (Bromophenol blue) was added in $10 \mu \mathrm{l}$ of the digested products and mixed properly. The mixture was then loaded in the wells. The digested products fragments were electrophoresed in $3 \% \mathrm{w} / \mathrm{v}$ agarose gel which was stained with ethidium bromide, at $60 \mathrm{~V} 1 \mathrm{hr}$ in $1 \mathrm{X}$ TBE buffer. The gel was then viewed under gel documentation system and images were captured. For comparison, an undigested sample was also loaded in one well and ran along with RE digests.

\section{Estimation of restricted fragments size and sequencing of the DNA samples}

The lengths of the fragments one must obtain after restriction digestion are $78 / 52 / 36 \mathrm{bp}$ for AA, 114/52 bp for BB and 114/78/52/36 bp for AB. To confirm the $\alpha$-lactalbumin genotypes the amplicons for the gene were eluted and sent for sequencing. For elution, amplicons were electrophoresed in $1 \%$ low melting agarose stained with ethidium bromide, at $80 \mathrm{~V}$ for 30 minutes in $1 \mathrm{X}$ TAE buffer. The gel was then viewed under UV trans-illuminator in very low intensity in order to avoid any UV induced mutation in the amplified DNA. DNA was purified using the GeneJET gel extraction kit (Thermo Scientific). The sequencing of DNA was done by Sanger's method. The sequences were then analyzed using software i.e. BLAST, Clustal Omega (multiple sequence alignment tool) for SNP detection and refined manually. The confirmation of the restriction digestion patterns was done by sequencing.

\section{RESULTS AND DISCUSSION}

Identification of $\alpha$-lactalbumin genotypes was performed by PCR-RFLP test and to confirm the lengths of PCR product of $166 \mathrm{bp}$, gel electrophoresis was performed. The results obtained from the study showed that polymorphism exist in HF Crossbred cattle and the enzyme has cut the amplicons in 114/52 bp for "BB" and 114/78/52/36 bp for "AB". Heterozygote "AB" was a combination of A and $B$ i.e. four fragments of 114/78/52/36 bp. "AA" genotype was not found in the population studied (Fig. 1).

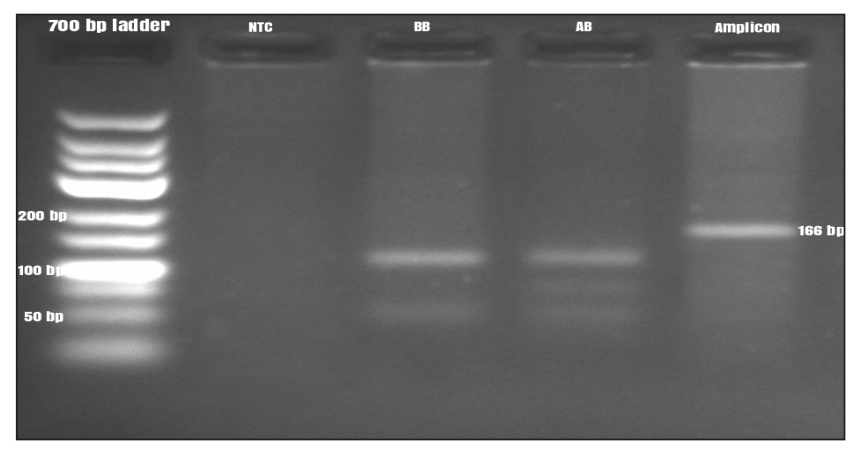

Fig. 1: PCR-RFLP indicating two genotypes (AB and BB)

Similar results were found by other researchers (Vătăsescubalcan, 2008) and only BB genotype was detected by them in the population studied. Results observed by some researchers (Miluchova et al., 2014) showed dominance of heterozygous genotype $\mathrm{AB}(0.8023)$ for gene LALBA in the cattle population. The other two homozygous genotypes AA (0.0581) and BB (0.1396) were represented in lower number. Their results suggest that the frequencies of allele A (0.4593) and allele B (0.5407) were nearly equal. The allele frequencies are presented below (Table 3). Chi-square statistic was not significant $(\mathrm{p}>0.05)$, indicating that the population was in Hardy-Weinberg equilibrium with respect to $\alpha$-lactalbumin gene locus. 
Table 3: Gene and genotype frequency LALBA gene

\begin{tabular}{llll}
\hline Frequency & Type & N & $\begin{array}{l}\text { Observed Frequency } \\
(\%)\end{array}$ \\
\hline \multirow{2}{*}{ Genotype } & AB & 12 & 0.2 \\
\multirow{2}{*}{ Gene } & BB & 48 & 0.8 \\
& A & & 0.1 \\
& B & & 0.9 \\
\hline
\end{tabular}

Through sequencing the genotype obtained were analyzed and only "AB" and "BB" variant was found in the population (Fig. 2, 3).

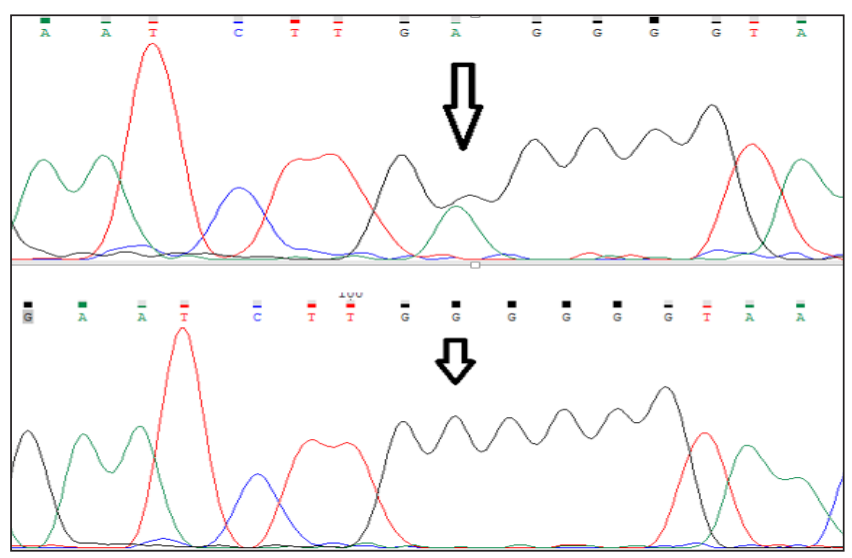

Fig. 2: Sequenced sample result showing a point mutation at 96 position for $\mathrm{G}>\mathrm{A}$

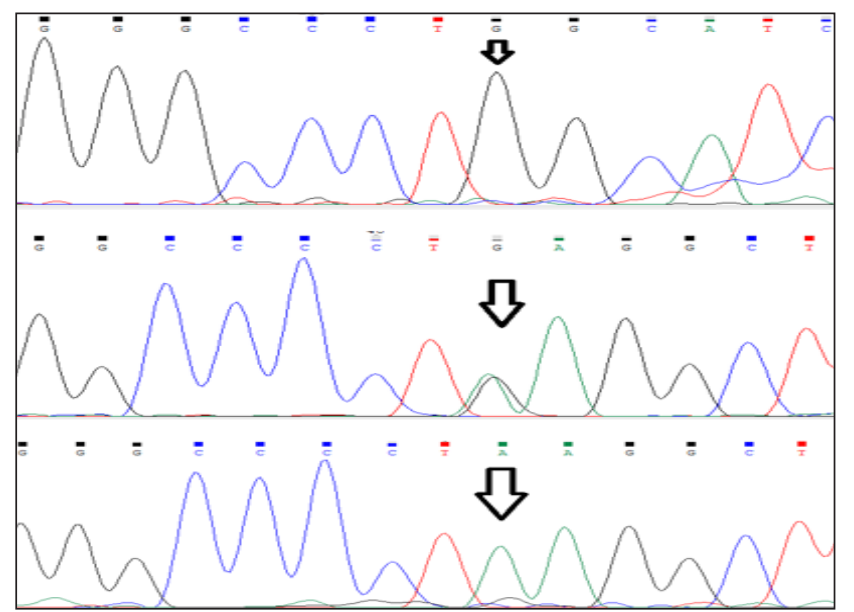

Fig. 3: Sequenced sample result showing a point mutation at 37 position for $\mathrm{A}>\mathrm{G}$

Sequencing identified and validated the presence of restriction site for MnlI enzyme in LALBA gene.
Sequenced PCR products of LALBA gene subjected to sequence alignment using clustal omega tool revealed two SNP's in the whole 166 bp fragment, one SNP is present in the untranslated region of exon (G96A) and one in the promoter region (A37G) (Fig. 4). Gene regulation study using Alibaba software tool (http://gene-regulation.com/ pub/programs/alibaba2/) revealed "Antp" transcription factor not binding at 35 to $44 \mathrm{bp}$ due to point mutation at $37 \mathrm{bp}$ of $\mathrm{A}>\mathrm{G}$, suggesting modulation of transcription. Further investigation will be required to elucidate the biological and practical relevance of these SNP's and change in transcription factor.

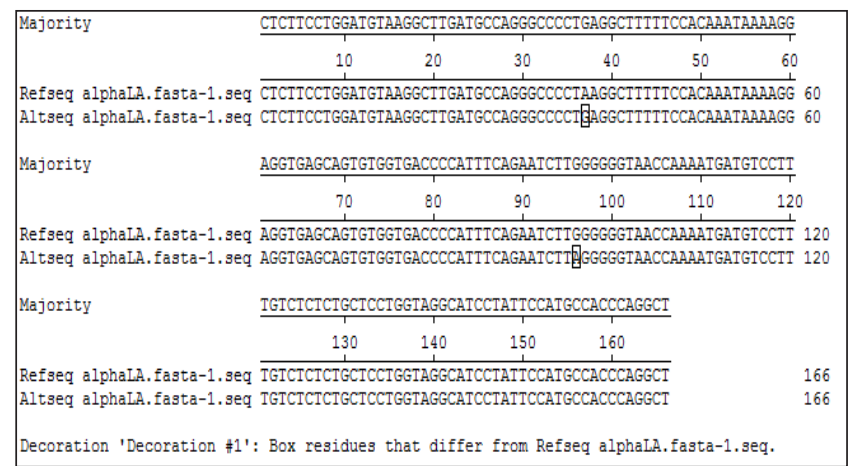

Fig. 4: Alignment of sequenced sample results with reported NCBI sequence showing two SNP's in $\alpha$-lactalbumin amplicon

Investigation of the polymorphism with performance traits revealed significant $(\mathrm{p}<0.05)$ association of $\alpha$-lactalbumin gene "BB" genotype with high FLPY, while both variants showed non-significant effects on other milk production and reproductive performance traits, which may be helpful in evaluation of animals with favorable genotype for the milk production trait (Table 4). Research done on Chinese Holstein cow (Zhou and Dong, 2013) revealed $\alpha$-LA2516 SNP, which showed no association with milk yield, protein percentage, fat percentage, or somatic cell score where as other study (Zhang et al., 2007) on Chinese Holsteins found no significant associations between the two polymorphisms and the five milk performance traits $(\mathrm{p}>0.05)$ used.

\section{CONCLUSION}

The study demonstrated the possible association between genetic variants of LALBA gene with first lactation peak yield. Among the two found "AB" and "BB" genotype 
Table 4: Least squares means and standard errors for performance parameters of different genotypes of $\alpha$-lactalbumin gene

\begin{tabular}{|c|c|c|c|c|c|c|c|c|c|c|}
\hline Gene & Genotype & FLMY & FL305MY & FLL & FCI & FDP & FLPY & DMY & WFC & FSP \\
\hline \multirow[b]{2}{*}{$\alpha$-lactalbumin } & $\mathrm{BB}$ & $\begin{array}{l}4774.2 \pm \\
365.36\end{array}$ & $\begin{array}{l}3646.54 \pm \\
183.2\end{array}$ & $\begin{array}{l}444.3 \pm \\
29.31\end{array}$ & $\begin{array}{l}470.69 \pm \\
24.07\end{array}$ & $\begin{array}{l}59.28 \pm \\
9.48\end{array}$ & $\begin{array}{l}20.87^{\mathrm{a}} \pm \\
0.67\end{array}$ & $\begin{array}{l}46.76 \pm \\
3.57\end{array}$ & $\begin{array}{l}409.18 \pm \\
5.21\end{array}$ & $\begin{array}{l}204.47 \pm \\
23.08\end{array}$ \\
\hline & $\mathrm{AB}$ & $\begin{array}{l}4788.56 \pm \\
730.72\end{array}$ & $\begin{array}{l}3934.75 \pm \\
366.39\end{array}$ & $\begin{array}{l}397.59 \pm \\
58.61\end{array}$ & $\begin{array}{l}484.41 \pm \\
46.08\end{array}$ & $\begin{array}{l}88.24 \pm \\
18.14\end{array}$ & $\begin{array}{l}17.62^{\mathrm{b}} \pm \\
1.34\end{array}$ & $\begin{array}{l}47.66 \pm \\
7.14\end{array}$ & $\begin{array}{l}407.9 \pm \\
10.41\end{array}$ & $\begin{array}{l}188.79 \pm \\
44.2\end{array}$ \\
\hline
\end{tabular}

Mean values bearing different superscript differ significantly $(\mathrm{P} \leq 0.05)$.

in the population, animals with "BB" genotype showed significantly $(\mathrm{p} \leq 0.05)$ high FLPY. Gene regulation study showed "Antp" transcription factor not binding at 35 to $44 \mathrm{bp}$ due to point mutation at $37 \mathrm{bp} \mathrm{A}>\mathrm{G}$, suggesting modulation of transcription. Further investigations are required to elucidate the biological and practical relevance of these SNP's and change in transcription factor.

\section{ACKNOWLEDGEMENTS}

The authors are thankful to the Director, Livestock Farm, Guru Angad Dev Veterinary and Animal Sciences University, Ludhiana-141012, Punjab for providing necessary facilities to carry out the research work.

\section{REFERENCES}

Barłowska, J., Wolanciuk, A., Litwińczuk, Z. and Król, J. 2012. Milk Proteins' Polymorphism in Various Species of Animals Associated with Milk Production Utility. Milk Protein Walter L. Hurley, IntechOpen.

Harvey, W.R. 1990. Mixed model least squares and maximum likelihood computer program. PC-Version 2. Ohio State University, Columbus, USA (Mimeograph).

Hristov, P. and Radoslavov, G. 2015. A Review of Methods for Genotyping Milk Proteins in Cattle. J. Adv. Dairy Res., 3(3): 144.

Miluchova, M., Gabor, M. and Trakovicka, A. 2014. Analysis of genetic structure in Slovak pinzgau cattle using five candidate genes related to milk production traits. Genetika, 46(3): 865-875.
Sambrook, J. and Russell, D.W. 2001. Molecular cloning: a laboratory manual, $3^{\text {rd }}$ ed. NY: Cold Spring Harbor Laboratory Press.

Teneva, A. and Petrović, P.M. 2010. Application of molecular markers in livestock improvement. Biotech. Anim. Hus., 26(3-4): 135-54.

Vătăsescu-balcan, R.A., Georgescu, S.E., Adina, M.M., Anca, D., Tesio, C.D. and Marieta, C. 2008. Alpha-lactalbumin genotypes identification in Romanian Black Spotted cattle breed. Scientific Papers Anim. Sci. Biotech., 41(1): 169-73.

Zaglool, W.A., Awad, A., El Araby El, S.I. and El-Bayomi, M.K. 2016. Association of $\beta$ - lactoglobulin gene polymorphism with milk yield, fat and protein in Holstein-Friesian cattle. World Vet. J., 6(3): 117-22.

Zhang, J., Sun, D., Womack, E.J., Zhang, Y., Wang, Y. and Zhang, Y. 2007. Polymorphism identification, RH mapping and association of $\alpha$-lactalbumin gene with milk performance traits in Chinese Holstein. Asian-Australasian J. Anim. Sci., 20(9): 1327-1333.

Zhou, P.J. and Dong H.C. 2013. Association between a polymorphism of the $\alpha$-lactalbumin gene and milk production traits in Chinese Holstein cows. Gene. Molec. Res., 12(3): 3375-82. 
